Archives de sciences sociales des religions

177 | 2017

Mondes juifs en mouvement

\title{
Boundary crossers
}

The "Jewish Buddhists" and Judaism's symbolic boundaries in a global age

Passeurs de frontières. Les "juifs-bouddhistes " et les frontières symboliques du judaïsme à l'ère de la globalisation religieuse

Contrabandistas fronteras. Los límites "judíos budistas" y simbólicos del

judaísmo a la era de la globalización religiosa

\section{Mira Niculescu}

\section{CpenEdition}

\section{Journals}

Electronic version

URL: http://journals.openedition.org/assr/29318

DOI: $10.4000 /$ assr.29318

ISSN: $1777-5825$

Publisher

Éditions de l'EHESS

Printed version

Date of publication: 1 March 2017

Number of pages: 157-175

ISSN: 0335-5985

\section{Electronic reference}

Mira Niculescu, "Boundary crossers", Archives de sciences sociales des religions [Online], 177 | 2017, Online since 01 March 2019, connection on 05 January 2021. URL: http://journals.openedition.org/ assr/29318; DOI: https://doi.org/10.4000/assr.29318 


\section{Mira Niculescu}

\section{Boundary crossers}

\section{The "Jewish Buddhists" and Judaism's symbolic boundaries in a global age}

In the late sixties in New York, a college student named Suzanne Krieg was taken by her parents to a "cult clinic" because she was practicing Zen meditation. There a doctor was to have a conversation with her and determine if she was sane or had lost her mind. "He had the power to have me locked up in an institution," she recalled during our interview at the San Francisco Zen Center in the summer of 2009. She has now been a resident Buddhist nun there for more than a decade. Today, in the same city, synagogue Beth Shalom, a large American mainstream conservative congregation, has a meditation room in which rows of dark blue Zen meditation cushions await congregants before their prayer services ${ }^{1}$. This is not an exception. Increasingly over the last decade, throughout the United States, but also in Israel, Canada, Australia, England and even France, "Jewish meditation," whether Buddhist-inspired or traditionally Jewish, is being offered in Jewish institutions of all denominations.

How did such a cultural change occur, in such a short time? How did we get from denunciations of Buddhist meditation as "cultic" not even five decades ago, to seeing "meditation" classes throughout the Western Jewish world today?

I would like to suggest that it is those who are called "jewish Buddhists" themselves who have been instrumental in bringing about this change.

Jewish Buddhists - or Jubus, as they have been called since the publication of the Jew in the lotus (Kamenetz, 1994), can be roughly defined as Jews who claim to be connected both to Judaism and Buddhism. After its beginnings in Europe at the turn of the twentieth century (Baumann, 1997), this phenomenon mainly appeared in America with the counterculture of the sixties. Studies speak today of Jewish Buddhists in various Western counties: in Canada (Vallely, 2008), France (Obadia, 2007, 2015; Niculescu, 2014) and Israel (Loss, 2010; Pagis, 2015). Still, the "Jewish Buddhists" phenomenon remains mainly an American one. This is why in this article I will focus on

1. URL: http://bethsholomsf.org/, last accessed October $20^{\text {th }}, 2016$. 
the American scene. There, since its popularization subsequent to the Jew in the lotus, the phenomenon has been increasingly addressed in the Jewish press, in popular literature, and on the internet. Yet in spite of their growing visibility, Jewish Buddhists remain a marginal phenomenon within the Jewish world. The few studies published have estimated that they represent from $3 \%$ or $16 \%$ (Coleman, 1999: 95) to $30 \%$ (Linzer, 1996:12) of the Buddhist practitioners in America ${ }^{2}$, and comprise about $50 \%$ (Linzer, ib.) of the Western scholars of Buddhism. While these numbers become more noticeable when considering that American Jews form less than $3 \%$ of the American population, this phenomenon remains quantitatively marginal: according to a recent evaluation, no more than $5 \%$ of American Jews would call themselves “jubus” (Boys, 1997: 17).

Jewish Buddhists are therefore twice marginal: quantitatively, they are a minority within the Jewish field; symbolically, they stand on Judaism's symbolic borders.

Because this phenomenon mostly consists in a constellation of individual strategies of subjective bricolage between Judaism and Buddhism, it has largely been viewed through the lens of individualism: most works on the topic have been describing it as a subjective dialectical journey, from Judaism to Buddhism and back (Linzer, 1996; Vallely, 2008; Obadia, 2015; Niculescu, 2014). From a sociological perspective, in previous articles, I have looked it from the perspective of the relationship between the individual and Jewish institutions (Niculescu, 2012, 2014). Here I address this relation again, but this time focusing, not on the reactions of the system but rather on the way individuals impact it.

Using Barth's concept of “agents of change" (1969) to explain cultural change, I look at the shifts in Judaism's symbolic boundaries caused by the Jewish Buddhist's own positions and choices. I consider how Jewish Buddhists, through their own individual spiritual and professional trajectories, have made a collective impact on the Jewish field over the last four decades.

Using Bourdieu's conception of religion as a language, and of religious groups as fields of human activity governed by the relationship between supply and demand (1971), I suggest that by acting as importers and translators of Buddhist meditation within the Jewish world, Jewish Buddhists have caused Judaism's symbolic boundaries to shift, both externally and internally. Externally, they have done so by inviting Buddhist-derived practices to enter the contemporary Jewish spiritual supply, thereby increasing the porosity of Judaism's outside boundaries; and internally, they have done so by triggering, directly or indirectly, the growth of the practice of meditation as a new spiritual supply within the mainstream Jewish world. By doing so, I will argue that they have caused a reshaping of the Jewish religious field.

2. In addition, because they do not form a proper religious group but rather a constellation of individual postures, it is difficult to assess their actual demographic weight. 
In this article, I describe these processes as an example of the way individual strategies can impact a religious group - that is, in Barth's terms, how the margins can impact the center.

Through ethnographic interviews and the Critical Discourse Analysis (Fairclough, 1995) of the writing of six American born Jewish teachers, I will try to show these processes by focusing on the trajectory of these "agents of change".

\section{Boundary breakers: the counter-culture, the dharma, and the Jews}

After an early start in Europe at the dawn of the twentieth century when Jewish intellectuals were discovering the teachings of the Buddha (Baumann, 1997), the phenomenon of the "Jewish Buddhists" really took off after World War II. It did so especially with the rise of the counter-culture, a broad cultural movement sparked by the educated middle and upper class within the baby boomer generation. Responding to the deep upheaval shaking the Western culture they had been born into (the aftermath of World War $\mathrm{II}^{3}$, the Shoah and the atomic bomb, the decolonization conflicts, the Cold War, and the persistence of social and racial inequalities ${ }^{4}$ ), they set out to go "against" the norms and values of the culture of their parents, and experimented with new ways of being in the world- hence the expression "counter-culture." Although mainly in America, the counter-culture was also speaking in England and France, speaking to a deep general crisis of Western modernity.

Such was the fertile ground of a cultural protest movement, which led many students, artists and intellectuals- to turn into a "generation of seekers." (Roof, 1993). They were called "seekers" precisely because, while relinquishing the religions of their fathers (namely Judaism and Christianity), they were in search of spiritual alternatives. And in this search, many "turned East" (Cox, 1978 ) towards other belief and practice systems. They did so just in time to meet the globalization of Buddhism, Hinduism and yoga (Baumann, 2001; Baumann and Prebish, 2002; Turner and Khondker, 2010), a trend expressed in particular via the transnationalization of religious groups from various Asian countries (India, Japan, Tibet $)^{5}$. Indeed, as Roof puts it aptly:

The counterculture sensitized the better educated to new values and experiences, encouraging them to be more open and experimental in matters ranging from family and sexual styles to religious views. The so-called "new religions" - Zen Buddhism, Meher Baba, transcendental meditation, and many others - also flourished, introducing students to eastern spirituality (1993: 51).

3. Culminating with the two traumatic events of the Shoah and the Atomic bomb.

4. Both on a national and on an international scale.

5. Although perceived as utterly Asian, these practices had already been westernized even before their missionary exportation towards the West. See Gil Fronsdal (1998: 165-180). 
The American Jewish-born Buddhist teacher Wes Nisker in his spiritual autobiography (aptly called The big bag, the baby boom and the Buddha) helps understand why so many young Westerners of his time would turn towards Buddhism in particular:

We were born into a time of physical and metaphysical disruption, of homelessness and uncertainty [...] We lived through so many revolutions - social, political, sexual, and scientific - that our heads are now permanently spinning (2003: 9, 13).

The exploration into other spiritual paths was either facilitated by an already existing disconnection with inherited Western religions, as was the case for Nisker, or paired with a relinquishing thereof: Roof reports that in his study, "over $60 \%$ of the young adults [...] dropped out of active involvement for a period of two years or more". A figure, he specifies, that is "somewhat higher for Jews and mainline Protestants" (2003: 55).

Indeed, among the Western "spiritual seekers," especially in the newly emergent Western Buddhist circles, the number of American Jews was noticeable (Prebish, 1998: 2; Coleman, 1999: 95). Why were these baby boomers, mostly from Ashkenazi ${ }^{6}$ secular backgrounds ${ }^{7}$ so attracted by the teachings of the dharma ${ }^{8}$ ? While most scholars studying the Jewish Buddhist phenomenon have argued that the choice of Buddhism for the Jews had to be understood as a direct reaction to a spiritual crisis triggered by the Shoah (Linzer, 1997; Gez, 2011), Nisker's account suggests other motives:

For me, as for others of my generation, the teachings of the Buddha spoke directly to my personal confusion. Many of us lived with a perpetual identity crisis, and Buddhist meditation practices promised to get us to the bottom of the issue of "self," or even better, well beyond it. Buddhism also offered us the solace of vast perspectives and methods to cope with the torrents of change we were experiencing (2003: 14).

For Nisker, Buddhist practice was simply the best ways to help young Westerners like himself cope with existential anxiety. This resonates with the majority of my respondents' accounts, including those whose profiles are described below. Yet both interpretations are correct. As I have suggested elsewhere (Niculescu, 2014), what made Jews proportionally more visible in Buddhist circles can be explained by three other factors: first, Buddhism, as a non-theistic path, was not contradicting directly Judaism's prohibition of idolatry; second, adhering to Buddhism was less taboo than adhering to Christianity or Islam (two competing monotheistic religions and two cultures with which Jewish communities had sad historical records of conflict and religious oppression); and third, Buddhism addressed the question of suffering, which had been central throughout Jewish history and had just painfully

6. Ashkenazi Jewry is from Eastern Europe and was particularly touched by the Shoah.

7. For the first assessment, from a fieldwork done in the seventies in California, see Judith Linzer (1996), for direct observations in the nineties, see Roger Kamenetz (1994).

8. The teaching of the Buddha, which Westerners commonly call "Buddhism." 
climaxed with the Shoah. Together, all these reasons may explain the Jewish visibility in the new Western Buddhist circles (cf. Kamenetz, 1994; Lew, 1999; Nisker, 2003).

By embracing Buddhist practice, these individuals crossed Judaism's religious symbolic boundaries. But they became an unusual type of boundary crossers: ones that stay on the border line. The reason was that for them, adopting Buddhism did not mean ceasing to be a Jew. Nisker for example, a Buddhist teacher with no formal ties with Judaism, asserts: "Through it all, I still considered myself Jewish. Maybe that's because you can't convert out of being Jewish just as you can't convert out of being Italian” (2003: 12).

Even more so, for many, as we will see, embracing Buddhism actually led them to eventually come closer to Judaism, either informally (through (re) connecting to Jewish spirituality) or formally (through (re)connecting to some form of religious practice $\left.{ }^{9}\right)$. Indeed, what is significant about the phenomenon of the Jewish Buddhists, as scholars observing the phenomenon in the seventies in California (Linzer, 1997) and in the early 2000's in Canada (Vallely, 2008) and in France (Obadia, 2015; Niculescu, 2014) have noticed, many of those who are called "Jewish Buddhists" claim to have "come back" to Judaism, as an effect of their Buddhist practice.

This movement of "return to religion", although not systematic, is a core characteristic of a "seeker generation": according to Roof, "what is really significant religiously is not that they drift away, but whether or not they return to these institutions later on in their lives - which many are now doing" (1993, p. 56). This is why it is important to understand that Jewish Buddhists are not just Jewish-born individuals who crossed over to Buddhism. They are those individuals who subsequently crossed over again back to Judaism - to various degrees and extents, thus completing a dialectical process of "exile and return" (Vallely, 2008: 23). And what makes it a social phenomenon rather than a quiet constellation of individual bricolages, is that for some of them, crossing back meant taking initiative, especially in introducing other Jews to meditation, either Buddhist, or Jewish, or both. By doing so, they turned into "agents of change."

"Agents of change" is a concept introduced by Norwegian sociologist Frederik Barth in his study on "ethnic groups and boundaries." When examining the processes of "culture contact and change" (1969: 31), he focuses on the charcters of "agents of change," which he calls "innovators." For him, "agents of change" are individuals, generally coming from the elite of a given culture, who make the larger cultural boundaries shift due to the impact of their own choices and positioning vis à vis the system. This is why for Barth, when wanting to understand boundary change, one has to look at these individuals, "examine the strategies that are open and attractive to them,

9. I distinguish between "religion" and "spirituality" the way Roof's does between "spirit" and "institution" as the "inner, experiential aspect" and the "outer, established form of religion" (1993: 30). 
and wonder what are the organizational implications of different choices on their part” (1969: 3).

\section{Boundary blurrers: six Jewish characters in quest of their story via Buddhist practice}

Let us now look at the specific "agents of change" whose action will be described below. They are middle or upper-class American-born Ashkenazi Jews from the East and West Coasts (mainly the New York or Los Angeles areas). With the exception of Maisels and Lester, who are born in early seventies, they are all frm the Baby boomer generation, born after World War II. Except Lew, who passed away a few months before I first came to San Francisco, I interviewed each of them between 2009 and 2016, in San Francisco, New York or Jerusalem. The quick portraits below are extracted from these interviews and in some cases from their autobiographical writings. Whatever Jewish world they came from - secular, reform, conservative or orthodox, they have comparable landmarks in their trajectories: they were all exposed to Judaism in their primary childhood, from which they have kept positive memories; they all have chosen to practice Buddhist meditation because they were in search of something they could not find in Judaism (spirituality, existential answers, a concrete account of the truth of their life experience, an efficient pragmatic method to cope with anxiety...); they are all today teachers of meditation: either Jewish, or Buddhist, or both.

I present them here gradually according to their Jewish background: from the least orthodox to the most, although no profile is clear-cut.

Alan Lew was born in Brooklyn to a family in which half of his grandparents were observant - his grandfather was an orthodox rabbi, and half, not. After spending the first years of his life in the traditional world of Yiddish Brooklyn, as his family followed the gentrification pattern and moved to the residential suburbs of New York, his life still became totally secular. After a long spiritual search during which he looked into many spiritual paths in a quest for inner peace and coherence, Lew engaged thoroughly in Zen meditation. After ten years of practice, while he was about to be ordained a Zen monk, he realized he could not totally cross to the other side. Here is how he explains this moment:

The problem wasn't that I felt I was betraying god. In fact, when I was sitting in zazen, I often felt more in contact with god than I ever had before. But I felt I was betraying my soul. Mine was a Jewish soul. I was betraying myself. [...] Zen meditation, which focused on the present moment [...], allowed me to overhear the constant arguments going on in my head. Now I heard something else, underneath, after all the veils were drawn back. I confronted my essence, and my essence was Jewish (Lew, 1999: 120).

Of course, this account, which comes from Lew's spiritual autobiography, is a reconstructed exemplary narrative aiming to be inspirational, as are most 
retrospective accounts of conversion (Tank-Storper, 2007). Yet it gives us a glimpse into this moment of symbolic border crossing, and at the inner limits that can be felt at different points by different people. For Lew, that meant returning within the fold of Judaism's symbolic boundaries: after this turning point, Lew decided to become a rabbi.

Hillel Lester grew up in a Reformed community in Orange County, California. Soon disappointed by synagogue life which as a teenager he found "not beautiful, not engaging, ${ }^{10 "}$ " he started exploring other spiritualities, namely Tibetan and Zen Buddhism. Towards the end of high school, when his parents got involved with the Jewish Renewal movement, he started learning with David Cooper, a Renewal rabbi who had spent decades meditating in the Sufi and Vipassana worlds, and who was teaching ecumenical forms of Jewish meditation informed by these other traditions. Over the years, Lester became more orthodox and more interested in meditation practices that are specifically Jewish. He eventually moved to Israel and joined a neo-Hassidic Zionist yeshiva, where he was ordained a rabbi.

Norman Fischer was a close friend of Lew's. He grew up in a traditionalist Conservative Jewish world near Philadelphia, and enjoyed the Jewish learning he was provided with. But as soon as he became a young adult, he decided to explore other paths, because he felt Judaism was not addressing his existential questions.

When a passion for truth, for the real, began to consume me. It simply never occurred to me to seek answers in Judaism, in any other religion for that matter. In fact, to me, religion seemed the opposite of what I was interested in. I was consumed with questions (2003: 253).

Fischer's critique of Judaism frames itself as a critique of organized religion in general. In that sense, he is representative of most Buddhist Jews, which take Buddhism not as a religion but as a "spirituality" - in the Foucaldian sense of spiritual practice as a "practice of the self" - une "pratique de soi" - (1981-1982). When he moved to San Francisco, Fischer started practicing intensely Zen meditation, became a Zen monk, and received the prestigious title of Zen Abbot. The death of his mother brought him back to the synagogue and closer to Jewish practice - although in an autobiographic article, he specified for his readers that this was for him "more of a family tradition rather than an individual quest ${ }^{11}$."

In her spiritual autobiography (1997), Sylvia Boorstein declares she had only good memories of the orthodox Brooklyn world she was born into - a world which she describes as traditionalist, open and warm. Yet once married and away from this very Jewish New York world, she progressively parted from its lifestyle and became less and less observant. Confronted later on in life by

10. Interview, Jerusalem, June 2015.

11. URL: http://www.Dharmalife.com/issue18/roshiandrabbi.html, last accessed October $20^{\text {th }}$, 2016. 
existential angst, she tried Buddhist meditation, under the recommendations of her husband who had been himself a spiritual seeker and had explored many paths. Sylvia was very taken by Insight Meditation, a Western translation of the Vipassana school of Buddhism, and after years of practice, she became a Buddhist teacher. At the opening of her autobiographical book on being both "a faithful Jew and a passionate Buddhist," she recounts how Judaism suddenly resurfaced in her spiritual life, along her Buddhist practice:

In the middle of a Buddhist meditation retreat, my mind filled with a peace I had not known before - completely restful, balanced, alert, joyous peace - and I said, baruch hashem ("praise to god"). The next thing I did was say the Hebrew blessing of thanksgiving for having lived long enough, for having been "sustained in life and allowed to reach" that day. The blessings arose spontaneously in my mind. I didn't plan them. My prayer life in those days was a memory rather than a habit, but the blessing felt entirely natural (1997: 1).

Since then, without changing a thing in her career as a Buddhist teacher, she has invested again in Jewish prayer and learning which she integrates with her Dharma practice, and she has endeavored to teach meditation to rabbis (Niculescu, 2015).

James Maisels grew up in the Pennsylvania countryside in an Ashkenazi family from South Africa with an orthodox background. Yet for practical reasons, James' family joined a Conservative synagogue, and James grew up between traditional observance and more liberal accommodations. In college, he became more involved in Jewish life and observance. At the same time, he encountered meditation, upon the recommendation of therapists, as he was struggling with anxiety ${ }^{12}$. This led him to deepen his meditation practice, including within Buddhist groups, while not only retaining his Jewish practice, but wanting to go more deeply into Jewish spirituality. He moved to Israel to study in an American non-denominational coed Yeshiva, where he later received orthodox rabbinic ordination before completing a Ph.D. with Chicago University on Jewish mysticism. All the while, he started teaching "Jewish meditation": both traditional Jewish meditation and "Jewish mindfulness": a meditation technique derived from Buddhist Insight Meditation and applied to Jewish practice (Niculescu, 2015).

Len Moskowitz grew up in a "very religious 13 " modern orthodox family on Long Island, New York. After completing his Yeshiva high school curriculum, he experienced a crisis, realizing he had never been explained "why" he was observing all the Jewish commandements he had been practicing all his life. "I didn't see why I should be Jewish.” So for a few years, he drifted in and out of the symbolic line of Halakha ${ }^{14}$ - "in" when he was at home with his parents, and "out" when on his own. A couple of years later, after learning about other

12. From a series of interviews: Jerusalem 2010, New York 2012, email exchanges 2016.

13. Excerpts from an interview, New York, September 2012.

14. Jewish law. 
faiths (Eastern spiritualities, Native American religion), he was convinced that the "truth claims of Judaism were valid", and decided to go back fully to orthodox Jewish observance. But he still kept looking for spiritual practices, and he could not find them in the Jewish world. So he started practicing zazen -but carefully, he specifies, "within the frame delimited by Halakha": taking on silent sitting, and leaving out the Buddhist tenets and rituals. Like Lester and Maisels, this led him to want to explore further the tradition of Jewish meditative practices. He later enrolled in Yeshiva University to become a rabbi and help inspire other Jews who had defected to Buddhism to return to Jewish spirituality. All the while he kept meditating, but in Jewish contexts, as he had met with Alan Lew and Norman Fischer, who were teaching silent sitting to Jewish audiences.

These quickly painted portraits show something noteworthy about Jewish identity and practice: Jewish worlds are not wholly coherent: lines are not always that clear-cut; most people grow up in families in which the relationship to Jewish observance varies according to the individuals but also to the time periods. Some family members are more observant than others, and are so at some times in their lives more than others. So in-betweeneness is already there. These lead to various reactions, and it seems that the more in-betweenness there is at the beginning, the more circulation and back-and-forth crossovers can be found in one's journey.

The most startling reversals are those of Fischer and Lew: the one raised observant became a Zen teacher, and the one raised secular became a rabbi. Lester and Maisels exemplify more progressive trajectories. Moskowitz, except for a brief period of exploration, has kept to his homogenous and coherent orthodox life.

Of course, not all Buddhist Jews become Buddhist teachers or rabbis. These are ideal typical cases. But these archetypal profiles help show the variety of cases subsumed under the expression "Jewish Buddhists:" Moskowitz and Maisels are observant Jews who practice the dharma for its silent meditation techniques while keeping to an orthodox Jewish lifestyle; Fischer and Boorstein are Buddhist teachers who reconnected with Jewish spirituality. Lester and Lew are observant Jews who have engaged in the dharma as an exploratory stage and who have kept its inspiration in the Jewish meditation practice they offer.

No matter how diverse these profiles, they have in common that they have been motivated, at some point, by a spiritual search: for enlightenment or spiritual experience in the cases of Lester and Moskovitz, for appeasing existential discomfort in the cases of Boorstein and Maisels, for truth and clarity in the cases of Fischer and Lew.

For all of them, there was an initial connection to Judaism followed by a moment of rupture due to search for a spirituality unfulfilled in Jewish life, and finally a reencounter with Judaism, in various ways and to various instincts. This dialectical pattern is very similar to both the spiritual path of the spiritual seekers described by Roof (1993), and of religious conversions 
in general (to Judaism: Tank-Storper, 2007 and to Buddhism: Koné, 2000). But the difference between the pattern of religious conversion and that of spiritual seekers, in our case, as well as the broader pattern of the "spirituality of seeking" described by Roof (1993), is that for the latter patterns, the stage of synthesis in the dialectical trajectory consists in some form of return to the starting point: to one's origin. This is what we see in the various profiles quoted above, whatever the extent of the recommitment to Judaism is.

Our six cases seem to exemplify three main forms of patterns: circular, vertical and horizontal.

Lester and especially Lew exemplify a circular dialectic path, in which Buddhism is a detour before reencountering Judaism.

Boorstein and Fisher embody a vertical one. The way they claim to find spiritual fulfilment both in their Jewish spiritual origin and in their Buddhist elected practice seems to embody the "Jewish roots and Buddhist petals" self-description by Marc Lieberman, the first Jubu described by Roger Kamenetz (1994: 12).

Moskowitz and Maisel, with a steady Jewish commitment that is only reinforced by their Buddhist exploration, can be seen as embodying a horizontal path: the linear cumulative path of the river that gathers other streams on its way to the sea.

\section{Letting a little dharma in: shifting external symbolic boundaries}

Let us now see how each of these characters have become "agents of change". One of the first and main ways that Buddhist-practicing Jews are acting of agents of change is by introducing Buddhism within the confines of Judaism's symbolic boundaries - namely, by teaching Buddhist, or Buddhist-derived, forms of meditation.

Those for whom this process is the more explicit are, unsurprisingly, the two Buddhist teachers in our sample: Boorstein and Fischer. To schematize, one could say that Boorstein is bringing Jews to the dharma while Fischer is bringing the dharma to the Jews.

Boorstein has been working for years to introducing Jews to the dharma. She was the first Buddhist teacher to train rabbis to Buddhist meditation (Niculescu, 2015) and was therefore very influential in the genesis of the practice of "Jewish mindfulness." In the summer of 2009, along with rabbis and other Jewish meditators, she held for the first time at the Spirit Rock Meditation Center, the second Western Insight Meditation center in America that she cofounded near San Francisco in the late eighties, a "Jewish mindfulness retreat." This was a classical Buddhist mindfulness retreat, adapted to a Jewish audience (with Buddha statues concealed, and with Kosher food). The retreat was a big success, and was reconvened every year since, but with a shift towards more Jewish content: the retreat left the premises of the Buddhist center, and the schedule included Jewish prayers and chanting every morning and a contemplative celebration of Shabbat. 
Fischer's endeavor was to bring the dharma to the Jews. Instead of having Jews come to Buddhist settings, he would go to Jewish settings in order to teach Buddhist meditation. In 2000, he accepted Lew's invitation to found Makor $\mathrm{Or}{ }^{15}$, a center for Jewish spirituality that organizes meditation sessions and retreats for Jews. With the passing of Lew in 2009, Fischer, the Zen abbot, started working with conservative Rabbi Dorothy Richman. There, he teaches contemplative practices for Shabbat and Jewish Holidays with the insights gained from his Buddhist practice. For instance, during Passover, the "passage", in which Jews celebrate their exodus from Egypt and freedom for slavery is being read through a Buddhist lens, as a practice bringing freedom from inner bondage (that is as freeing oneself from the enslavement of one's mind). Over the past few years, he has also increasingly engaged in teaching meditation in Jewish settings, with other Jewish Buddhist meditation teachers and rabbis. In a recent internet article, Fischer was mentioning that when a young American Jew came to see him in a Zen context, they both knew that "what (they) really were doing was Jewish meditation ${ }^{16}$."

So both Boorstein and Fischer's postures have shifted over the past few years towards more integration of Jewish content within their teachings, as they have gotten more involved with rabbis and started teaching in Jewish settings. This indicates that when the boundaries shift, they shift in both directions: it is not only the Jewish field that is impacted by the import of Buddhist content. As contacts multiply, Jewish Buddhist teachers themselves find their teaching more influenced by Jewish contents.

Less explicit approaches of bringing the dharma are exemplified in the works of rabbis Lew, Lester, Moskowitz and Maisels. Each have taken the practice of silent sitting from the Buddhist world and have integrated it within a Jewish frame. This integration can be seen on three different levels:

First, silent sitting meditation can be explicitly a practice borrowed from Buddhism and extracted from the Buddhist ritual frame in order to offer the tool of quiet meditation to Jews. This is what Lew did when he opened a meditation room in his Conservative synagogue in San Francisco. The practice would look very much like Zen meditation: simply sitting quietly - but without the Zen rituals, and within a Jewish space and time - right before prayer services.

Second, silent sitting meditation can be presented as a proper hybrid Jewish practice: "Jewish mindfulness" (Niculescu, 2015). The extent of the secularization and the legitimation of Mindfulness Meditation within Jewish circles is such that orthodox rabbi Moskowitz is teaching it as part of his "Jewish Meditation class" at Yeshiva University in New York, the largest strictly Jewish orthodox Jewish university and seminar in the world:

15. URL: https://www.jccsf.org/adult/adult-classes/makor-or-Jewish-meditation/, last accessed October 20th, 2016.

16. URL: http://www.awakenedheartproject.org/articles/jewish-meditation-and-buber, last accessed January 12, 2017. 
"I teach three secular mindfulness techniques, to give our very stressed-out students the ability to reduce stress." But, at the very same time, he specifies: "And I teach why and how the non-Jewish meditation world (Buddhist, Hindu/Yoga, Christian, Muslim, and so-called secular) are almost completely off-limits to Jews who are serious about their Judaism." 17

We therefore witness a very interesting paradox: on the one hand, meditation techniques are extracted from the Buddhist tradition and taught in a strictly halakhic orthodox institution; on the other hand, a pedagogic effort is being made to explain to the students why Buddhist meditation is forbidden to them, as Jews.

This paradox between borrowing de facto while explicitly forbidding practicing Buddhist meditation is in fact neither surprising, nor new from the viewpoint of the Jewish history of cultural contacts. In fact, as the historian Beth Berkowitz shows in her book, Defining Jewish culture (2012), it is a classical mechanism by which rabbis have constantly allowed for cultural adaptation and borrowing while maintaining a strict principle of separation. This mechanism is the founding concept of Jewish culture (Douglas, 1966) - and for Arjun Appadurai the founding definition of any culture as "situated difference (2005: 12). The process consists in finding halakhic grounds to frame the scope of the borrowing so that it stays within the domain of the permitted. Hence for Moskovitz, silent meditation, as a quieting technique, is permitted for a Jew. What is not is the Jewish rituals and concepts that go with it in a Buddhist context ${ }^{18}$.

Hence, while the boundaries of Judaism are being made permeable to some Buddhist content, it is within a very defined and controlled frame. What matters is to maintain the idea of separation and of impermeability of Jewish symbolic boundaries, while allowing de facto the contacts and porousness which make any culture.

Third, silent sitting meditation can be presented in its specifically Jewish version. We have seen earlier that one of the main outcomes of the Jewish journeys towards Buddhism was a desire to reinvestigate and explore the Jewish tradition. One of the main consequences is the retrieving of many Jewish meditation techniques. Among the most famous of these techniques today is Hashkata, the "quieting" technique taught by the Piaceszner Rebbe, a Hassidic rabbi of the early twentieth century.

This technique, which is also the most similar to Buddhist silent meditation, is one of the main being taught today by orthodox rabbis who, like Maisels, Moskowitz and Lester, want to teach Jewish meditation to their peers.

These three strategies show the interplay between absorbing innovation and reappraising tradition. They are the mark of the work of "agents of change:"individuals who by their own actions end up impacting a system.

17. Email exchange, January 2017.

18. Interview, New York, September 2012. 
Although Barth's concept is meant to describe "political innovators," his portrayl of these agents is very relevant in the case of the "religious innovators" described above:

Much of the activity of political innovators is concerned with the codification of idioms: the selection of signals for identity and the assertion of value for these cultural diacritics, and the suppression or denial of relevance for other differentiae. The issue as to which new cultural forms are compatible with the native ethnic identity is often hotly contended, but is generally settled in favor of syncretism for the reasons noted above. But a great amount of attention may be paid to the revival of select traditional culture traits, and to the establishment of historical traditions to justify and glorify the idioms and the identity (Barth, 1969: 35).

What Barth depicts here fits very well with the way our teachers are tailoring their own hybrid theology; by highlighting some elements of each tradition and downplaying others. By so doing, they form a coherent system that becomes their unique teaching, and that integrates the hybridity that inevitably comes along with innovation, while emphasizing the way they each reappraise their tradition.

\section{Promoting Jewish meditation: reorganizing Judaism's internal boundaries}

If teaching meditation has been a way to impact Judaism's external boundaries, it has also impacted the center; by carving itself a place within the Jewish religious supply, meditation is changing the topography of the Jewish field itself.

This internal reorganization of Jewish institutional religion is caused by the introduction of Buddhist meditation techniques has been both direct and indirect. We have just seen an example of each above. The direct way is when Jewish meditation teachers teach Buddhist or Buddhist-derived meditation within a Jewish context. The indirect way is when rabbis start promoting Jewish meditation as a reaction to the success of Buddhist meditation. This started with the publication of Jewish Meditation, a best-selling book by orthodox Rabbi Aryeh Kaplan (1985), which aims at listing all the main traditional Jewish meditation techniques. Reading the references made to the attraction of the author's contemporaries to Eastern meditation in its introduction, it becomes clear that this meditation manual was compiled in order to respond to the Jewish interest in Buddhism and Hinduism.

But beyond the "reactive stance", popularizing Jewish traditional meditation is in itself a shift within Judaism's internal symbolic boundaries: for millennia, Jewish meditative practices have been esoteric, oral, and exclusive - reserved to a learned elite of male rabbis. But as I have explained elsewhere (Niculescu, 2014), 
the threat felt by the success of Buddhism has triggered creative responses ${ }^{19}$, under the above descrbied Jewish endeavors to popularize traditional Jewish spiritual practices. An example is the number of publications on "Jewish mindfulness" and Jewish meditation today on the website of "ultra-orthodox" outreach Lubavitch group Chabad ${ }^{20}$. This is why I have argued that the development of traditional Jewish meditation today has to be read as a competitive response to the success of Buddhism (Niculescu 2014).

Consequently, it can be said that the Jewish Buddhists phenomenon has indirectly caused another boundary shift, internal this time, under the form of a reorganization of the religious supply within the Jewish field. This internal reorganization of the Jewish field can be seen either when looking qualitatively, as we just did, at the changes in content, or when looking structurally at the emergence of new organizations.

More specifically, structurally speaking, it seems that there are four main ways by which Buddhist-practicing Jews are impacting the Jewish world: by publicizing their discourses; by entering Jewish institutions; by creating their own groups; and by establishing their own institutions.

By publicizing their discourses, I mean the publishing of books. In our examples, half of the teachers, the most senior ones, have published their spiritual autobiographies and teachings. Boorstein's That's funny you don't look Buddhist (1997) and Lew's One God clapping (1999), in particular, have since the late nineties become best-sellers in the Jewish world. These spiritual autobiographies have a triple impact: they are pedagogical in that they articulate for large audiences their author's positions with regards to Judaism and Buddhism; they are inspirational in that they offer exemplary discourses of the virtue of crossing the boundary between Judaism and Buddhism; and they are strategic in that they advertise for their authors as teachers. Through such publications, our innovators do not only appear as exemplary figures. They also play the role of cultural translators between the Buddhist and the Jewish world. Sometimes the translation between these two forms of spirituality is practice-based, as with Alan Lew's book, Be still and get going. A Jewish meditation practice for real life (2005), or Boorstein's, Don't just do something, sit there. A mindfulness retreat (1996). Sometimes the translation is more literally text-based. For instance, Norman Fischer has translated in Zen terms a selection of Jewish psalms in (2003b) and prayers, which are now used widely in American Jewish meditation settings.

The second manner of structurally impacting change in the Jewish field is by entering Jewish institutions. We saw above a striking example of Buddhist meditation techniques entering the orthodox institution Yeshiva University. This case is not isolated. Indeed, one main way that Buddhist meditation-

19. Jewish Historian Jacob Neusner also described the birth of Rabbinic Judaism as a creative response to exile and destruction (2004).

20. URL: http://www.chabad.org/library/article_cdo/aid/1442811/jewish/On-Mindfulness-andJewish-Meditation-Part-I.htm, last accessed January 12, 2017. 
practicing Jews are bringing change within the Jewish world is by introducing a new practice tool within Jewish institutions: synagogues, Jewish community centers, Jewish centers at various Universities, are now offering various forms of "Jewish meditation" clases. To give but a few examples, a " mindfulness project" at the Jewish "Bronfman Center" of New York University (NYU)," has been offering since 2010 meditation practices combined with teachings on the weekly Parasha, while Ha Makom, the Center for Jewish spirituality at the Manhattan Jewish Community Center (JCC), offers for about a decade, twice daily Buddhist-based meditation sessions. Likewise, today, synagogues from all the scope of Jewish denominations ${ }^{21}$ in America offer various types of "Jewish meditation classes."

A third way is by creating one's own new group, where meditation is taught in a Jewish setting. Such is the case Fischer and Lew's Makor Or mentioned above, Maisels' Center for Jewish Spirituality and Meditation Or Ha Lev, or Lester's Shalev Center for Jewish Personal Growth in Jerusalem.

Lastly, a major sign of the importance taken, within the contemporary Jewish religious field, of Buddhist-inspired or traditional Jewish meditation, is the creation of a new institutions dedicated to this discipline. Such is the case of the Institute for Jewish Spiritualty (IJS) in New York, founded by a group of Reconstructionist rabbis and practitioners of mindfulness meditation and dedicated to "cultivating Mindful Jewish Leaders." Since 2000, the IJS has trained more than 475 clergy members (rabbis and cantors), and led more than 70 "Jewish mindfulness retreats." Five years ago, it opened a "Jewish Mindfulness Teacher Training", that offers two years certifications. That there is today a training program and certificate of "Jewish mindfulness," a hybrid practice between Judaism and Buddhism, speaks to the boundary stretching that has occurred within Judaism since the sixties.

\section{The new global networks of Jewish meditation}

By turning the practices born out of their own choices and experiences into a new Jewish religious supply, Buddhism-practicing Jews have been reshaping the contours of the contemporary Jewish religious field. They are doing so both externally, by introducing a porosity between Jewish and Buddhist frames of spiritual practice, and internally, by carving a larger space for Jewish meditative practices - old and new, within the Jewish mainstream. But these are not the only borders that are being blurred. So are the spatial ones: in an increasingly interconnected world, these changes are going beyond American borders. This is not only because two among our six teachers, Maisels and Lester, have moved to Israel. But mostly because the newly created Jewish

21. Still very few from the orthodox world, but the orthodox world is also a minority today in the American Jewish world, representing less than $10 \%$ of Jewish affiliations according to the latest Pew study on American Judaism.URL: http:/www.pewforum.org/2013/10/01/Jewishamerican-beliefs-attitudes-culture-survey/, last accessed January 11, 2017. 
meditation groups are being created through and as transnational networks: Maisels travels several times a year to teach in America, but also England and Canada; the IJS has formed Jewish meditation teachers from England, Canada, New Zealand, and France, who are then encouraged to start their own "Jewish mindfulness" groups in their own home communities; Rabbis from America come regularly since 2009 to Israel to teach "Jewish Mindfulness" retreat, a field which is now developing as a new practice among English speaking Jews in Israel; and so it goes for orthodox groups who are reacting to this trend: Chabad offers strictly Jewish "Jewish meditation" classes in America, Australia, and all around the Jewish world.

As a result, Jewish meditation's “change agents" are impacting the Jewish field, not only locally but globally, as they are shaping new transnational networks along the preexisting lines of the Jewish diaspora (Niculescu, 2015). One of the predictable consequences of this globalization of Jewish spirituality seems, is that, paradoxically, rather than becoming more diverse as the consequence of personalized strategies of individual initiatives, the field of Jewish spirituality, may be become increasingly homogenous.

\section{Mira NICULESCU Centre d'études en sciences sociales du religieux (CéSor) École des Hautes Études en Sciences Sociales (EHESS) nicu@ehess.fr}

\section{Bibliography}

Appadurai Arjun, 2005, Modernity at large. Cultural dimensions of globalization, Mineapolis, University of Minesota Press.

BARTH Frederik, 1969, «Introduction », Barth F., Ethnic Groups and Boundaries: The Social Organization of Culture Difference, London, Allen \& Unwin, p. 9-38.

Baumann Martin, 1997, "Culture Contact and Valuation: Early German Buddhists and the Creation of a 'Buddhism in Protestant Shape'”, Numen, vol. 44, fasc. 3, p. 270-295.

-, 2001, "Global Buddhism: developmental periods, regional histories, and a new analytical perspective", Journal of Global Buddhism, 2, p. 1-43.

-, Prebish Charles, 2002, Westward dharma, Berkeley, University of California Press.

Berkowitz Beth, 2012, Defining Jewish difference. From antiquity to the present, New York, Cambridge University Press.

Внавна Homi, 1994, The location of culture, London, New York, Routledge.

Boorstein Sylvia, 1997, That's funny, you don't look Buddhist: on being a Faithful Jew and a Passionate Buddhist, San Francisco, Harper.

-, 1996, Don't just do something, sit there. A mindfulness retreat with Sylvia Boorstein, San Francisco, Harper San Francisco.

Bourdieu Pierre, 1971, "Genèse et structure du champ religieux ", Revue française de sociologie, vol. 12, p. 295-334. 
Boys Mary, 1997, Jewish Christian dialogue. One woman's experience, Mahwah, Paulist Press.

CoHen Shaye, 1999, The beginning of Jewishness: boundaries, varieties, uncertainties, Berkeley, University of California Press.

Coleman James Williams, 1999, "The new Buddhism: some empirical findings", Williams D.R., Queen C.S. (eds.), American Buddhism: Methods and Findings in Recent Scholarship, Richmond, United Kingdom, Curzon Press, p. 91-99.

Cox Harvey, 1978, Turning East: Why Americans Look to the Orient for Spirituality-And What That Search Can Mean to the West, New York, Simon \& Schuster.

Douglas Mary, 1966, Purity and danger. An analysis of concepts of pollution and taboo, London, Penguin.

FAIRCLOUgh Norman, 1995, Critical discourse analysis, London, Longman.

FIsCHER Norman, 2003 a, “A Buddhist perspective. Calling, being called”, Kasimow H., Keenan J. P., Klepinger Keenan L. (eds.), Beside still waters. Jews, Christians, and the way of the Buddha, Boston, Wisdom Publications, p. 251-260.

-, 2003 b, Opening to You: Zen-inspired Translations of the Psalms, New York, Viking Compass.

Fronsdal Gil, 1998, "Insight meditation in the United States: life, liberty and the pursuit of happiness", Prebish C., Tanaka K. (eds.), The faces of Buddhism in America, Berkeley, University of California Press, p. 165-180.

Kamenetz Rodger, 1994, The Jew in the Lotus: A Poet's Rediscovery of Jewish Identity in Buddhist India, San Francisco, California, Harper San Francisco.

KaPlan Aryeh, 1984, Jewish meditation, New York, Shocken Books.

Koné, Alioune, 2000, Le zen en Occident: un vieux vin dans une nouvelle bouteille? Ethnologie française, p. 535-543.

LAmont Michèle, Virag Molnar, 2002, "The study of boundaries in the Social sciences”, Annual Review of Sociology, 28, p. 167-95.

Lew Alan, Sherill Jaffe, 1999, One God clapping. The spiritual path of a Zen Rabbi, Woodstock, Vermont, Jewish lights publishing.

-, 2007, Be still and get going: A Jewish meditation practice for real life, New York, Little, Brown and Co.

Linzer Judith, 1996, Torah and Dharma: Jewish seekers in eastern religions, London, Johnson Aronson.

Loss Joseph, 2010, "Buddha-Dharma in Israel: Explicit Non-Religious and Implicit Non-Secular Localization of Religion", Nova Religio: The Journal of Alternative and Emergent Religions, 13, 4, p. 84-105.

NeusNER Jacob, 2004, Transformations in Ancient Judaism: Textual Evidence for Creative Responses to Crisis, Peabody, MA, Hendrickson.

Niculescu Mira, 2012, "I the Jew, I the Buddhist. Multi religious belonging as inner dialogue", Crosscurrents, p. 350-359.

-, 2013, "Find your inner god and breathe. Buddhism, Pop culture and Contemporary changes in American Judaism”, Gauthier T., Martikanen T. (eds.), Religion in Consumer Society, London, Ashgate, p. 91-108.

-, 2014, "Juif-bouddhiste”? Conflictualités internes autour de l'adoption du bouddhisme par des juifs français ", Lamine A.S (éd.) Quand le religieux fait conflit. Désaccords, négociations ou arrangements, Presses universitaires de Rennes, p. 137-148. 
-, 2015a, "Mind full of God. Jewish mindfulness as an offspring of Western Buddhism in America", Buddhism without borders, Quli N., Mitchell S. (eds.), New York, Suny Press, p. 143-160.

-, 2015b, "Going online and taking the plane. From San Francisco to Jerusalem. The physical and electronic networks of Jewish mindfulness", The Heidelberg Journal of Religions on the Internet, vol. 8., p. 98-114.

-, 2015c, «Se connecter et prendre l'avion. De San Francisco à Jérusalem en passant par Dharamsala: la nouvelle méditation juive en réseau ", Nizard S., Jonveaux I., Duteil-Ogata F., (éds.), Le religieux sur Internet, Paris, L'Harmattan, p. 140-155.

Nisker Wes, 2003, The big bang, the Buddha, and the baby-boom; the spiritual experiments of my generation, San Francisco, Harper.

Oвadia Lionel, 2002, «Bouddhisme et judaïsme», Socio-Anthropologie, n 12 , Traces. -, 2007, «Être juif et bouddhiste ", Attias J.-C., Benbassa E., Des cultures et des Dieux. Repères pour une transmission du fait religieux, Paris, Fayard, p. 412-413.

-, 2015, Shalom Bouddha. Judaïsme et bouddhisme une rencontre inattendue, Paris, Berg International.

PAGIs Michal, 2015, "Evoking equanimity: Silent interaction rituals in Vipassana meditation retreats", Qualitative Sociology, 38, 1, p. 39-56.

Prebish Charles, Tanaka Kenneth (eds.), 1998, The faces of Buddhism in America, Berkeley, University of California Press.

Roof Wade Clark, 1993, A Generation of Seekers: the Spiritual Journeys of the Baby Boom Generation, San Francisco, Harper.

Shoshanna Brenda, 2004, Jewish dharma. A guide to the practice of Judaism and Zen, New York, de Capo.

TANK-STORPer Sébastien, 2007, Juifs d'élection. Se convertir au judaïsme, Paris, CNRS Éditions.

Turner Bryan, Khondker Habibul, 2010, Globalization East and West, London, Sage. Vallely Anne, 2008, “Jewish redemption by way of the Buddha” Rothenberg C., Vallely A. (eds.), New Age Judaism, London, Vallentine Mitchell, p. 19-33.

\section{Boundary crossers. The "Jewish Buddhists" and Judaism's symbolic boundaries in a global age}

While the practice by Jews of Eastern meditation was sharply criticized in the Jewish world in the sixties, today, Buddhist-inspired new forms of "Jewish meditation" are being taught in most mainstream Jewish institutions in America and the Western world. What has led to such a turnaround? Using Barth's concept of "agents of change," the case studies of six American Jews teaching meditation shows how individual strategies can end up impacting the topography of a religious field, how the margins can impact the "center" of a religious group. As it reshapes Judaism's symbolic boundaries, both external and internal, the phenomenon of the Buddhist Jews invites us to 
rethink religion as a process constantly in the making, continuously shaped by individual choices and cultural interactions.

Key words: Jewish Buddhists, symbolic boundaries, boundary crossing, agents of change, religious globalization.

\section{Passeurs de frontières. Les "juifs-bouddhistes " et les frontières symboliques du judaïsme à l'ère de la globalisation religieuse}

Alors que les juifs qui pratiquaient les méditations orientales étaient virulemment critiqués au sein du monde juif dans les années soixante, aujourd'hui, de nouvelles formes de "méditation juive» inspirées $d u$ bouddhisme sont proposées dans la plupart des institutions juives américaines et occidentales mainstream. Comment un tel retournement a-t-il-pu s'opérer ? À partir du concept Barthien $d$ ' "agents du changement", l'étude de cas de six juifs américains enseignant la méditation montre comment des stratégies individuelles peuvent en venir à avoir un impact sur la topographie collective d'un champ religieux: comment dans un groupe religieux, les marges peuvent en venir à avoir un impact sur le "centre». Alors qu'il remodèle les frontières symboliques du judaïsme, externes comme internes, le phénomène des juifs-bouddhistes, nous invite à repenser la religion comme un processus continuellement en train de se faire, constamment en train de se (re)structurer au fil des choix individuels et des interactions culturelles.

Mots clés : Juifs-bouddhistes, frontières symboliques, passeurs de frontières, agents $d u$ changement, globalisation religieuse.

\section{Contrabandistas fronteras. Los límites "judíos budistas" y simbólicos del judaísmo a la era de la globalización religiosa}

Mientras Judios que practicaban las meditaciones orientales fueron criticados con virulencia en el mundo judio en los años sesenta la actualidad, las nuevas formas de "meditación judia», inspirado en el budismo están disponibles en la mayoría de las instituciones judias dominantes estadounidenses y occidentales. Como tal tiene una inversión que podría tener lugar-? De barthiano concepto de "agentes de cambio", voy a describir, a través del estudio de caso de seis maestro judío americano de la meditación, cómo las estrategias individuales pueden llegar a tener un impacto en la topografía colectiva de un campo religiosa cómo un grupo religioso, los márgenes puede llegar a tener un impacto en el "centro». A pesar de que cambia la forma de límites simbólicos del judaísmo, externa e interna, el fenómeno de la judía-budista, nos invita a reconsiderar la religión como un proceso continuo en la fabricación, constantemente en el proceso de (re) estructura sobre la la elección individual y las interacciones culturales.

Palabra claves: Judios, budistas, fronteras simbólicas, trascienden límites, agentes de cambio, la globalización religiosa. 